Mariani, M. A. P.; Amarilio, F. L.; Arruda, D. O. Pescadores profissionais urbanos de Corumbá/MS e suas relações com a atividade turística sustentável. Revista Brasileira de Ecoturismo,

\title{
Pescadores Profissionais Urbanos de Corumbá/MS e suas Relações com a Atividade Turística Sustentável
}

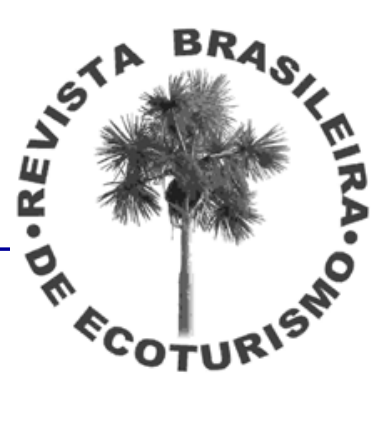

\author{
Milton Augusto Pasquotto Mariani, Francisco Leonor de Amarilio, \\ Dyego de Oliveira Arruda
}

\begin{abstract}
RESUMO
A pesca, seja em sua forma profissional ou amadora, é uma das principais atividades econômicas do Pantanal Sul, empregando e gerando renda para grande contingente de pessoas. No entanto, ela vem passando por um período de re-estruturação. Contemporaneamente, há estudos tratam de um prospecto de diminuição da pesca amadora, seja pela rigidez das leis ambientais ou pela diminuição dos estoques de pescado dos rios da região. Isso faz com que muitos pescadores profissionais se ressintam do fato, uma vez que eles, em certa medida, também dependem da pesca amadora. Desta feita, este estudo teve como objetivo elaborar um perfil dos anseios e percepções dos pescadores profissionais, de modo a estipular iniciativas que visem a atender suas principais demandas. Tendo isto em vista, foram aplicados 300 questionários semi-estruturados na área urbana de Corumbá com um grupo de pescadores profissionais, de modo que se constatou que é grande a possibilidade que esses indivíduos têm de se integrar a atividade do Ecoturismo, que apresenta visíveis meios de desenvolverse vertiginosamente na localidade em voga, gerando renda para a cidade, o que perfaz uma das principais demandas dos pescadores profissionais.
\end{abstract}

PALAVRAS-CHAVE: Pescadores Profissionais; Ecoturismo; Corumbá

\section{Professional Urban Fishermen from Corumbá/MS, Brazil, and their relationships with the Sustainable Touristic Activity}

\section{ABSTRACT}

Fishing, in its professional or amateur way, is one of the main economical activities in South Pantanal, which employs and generates income for a great deal of people. However, it has been passing through a period of restructuration. Contemporarily, there have been studies which show a prospect of decrease in the amateur fishing, due to the strictness of environmental laws or the reduction in fish stocks at the local rivers. This makes many professional fishermen feel resented as they, in a certain way, are also dependent on amateur fishing. Thefore, the study aims to make a profile of the professional fishermen's wishes and perceptions in such a way that initiatives to answer their main demands could be stipulated. By taking this fact into account, 300 semi-structured interviews were conducted in the urban area of Corumbá with a group of professional fishermen, in which it was stated that there is a high possibility of their integration into the Ecotourism activities, which show visible ways of development in the area, making it possible to generate income to the city, what meets one of the main professional fishermen's demands.

KEYWORDS: Professional Fishermen; Ecotourism; Corumbá. 


\section{INTRODUÇÃO}

A pesca é uma das principais atividades econômicas, sociais e ambientais desenvolvidas no Pantanal Sul-Mato-Grossense, praticada por uma gama de indivíduos, dentre os quais: os pescadores profissionais artesanais, que têm na atividade pesqueira sua principal fonte de renda, e utilizam na efetivação de seus trabalhos instrumentos de baixa predação ambiental (como a canoa de um pau, linhada de mão ou bóias com anzóis); os pescadores amadores que, via de regra, são turistas que praticam a pesca como forma de lazer e utilizam equipamentos com nível tecnológico agregado os mais diversos possíveis; e os indivíduos que capturam o pescado como mera forma de subsistência, artesanalmente, não comercializando o produto de seu trabalho.

Cada um dos sujeitos supracitados, com seus respectivos níveis de importância, traz benefícios, sejam diretos ou indiretos, para a cidade de Corumbá, receptáculo da atividade turística pesqueira que por ora analisa-se. Dentre os benefícios locais diretos pode-se citar a apropriação e venda do pescado, com a consequente geração de emprego e renda, movimentando a economia local. Não obstante, no que tange aos benefícios indiretos, faz-se mister salientar a expansão e fomento da atividade turística, com a consecução de seus decorrentes valores agregados - como a renda advinda de maior movimentação de bares, hotéis, restaurantes e empresas de turismo da localidade.

A exploração pesqueira no Pantanal é feita historicamente pelos pescadores profissionais que capturam e vendem o peixe in natura, sendo que há registros de que o volume de desembarque através desta atividade já foi bem maior que o percebido atualmente (MIGUEL VIEIRA, 1983, apud CATELLA, 2001). Não obstante, em detrimento da diminuição da pesca profissional, observa-se, sobretudo nas duas últimas décadas até o início do século XXI, um incremento crescente na pesca amadora, tanto em termos de número absoluto de visitantes, quanto em termos de pescado extraído dos rios por esses indivíduos.

Dentre os motivos que explicam a redução da atividade pesqueira profissional estão, sobretudo, a queda do quantitativo de peixes disponíveis para a pesca em virtude do aumento crescente do pescado extraído pelos pescadores amadores, além do baixo valor agregado da pesca profissional em comparação às movimentações decorrentes do turismo de pesca. Isso forçou muitos profissionais a abandonarem suas atividades pesqueiras quotidianas e se destinarem a funções que visam ao atendimento dos anseios dos turistas, como trabalhos de piloteiro, guia de pesca e catador de isca.

Nos dizeres de Catella (2003), a concorrência da pesca amadora (com impacto sobre o estoque pesqueiro) e as demandas por serviços a ela associada, fizeram com que muitos pescadores optassem por trabalhar como piloteiros, conduzindo os turistas na pesca esportiva ou amadora. Trata-se, notadamente, de um serviço paliativo e 
informal, que em detrimento das aparências que mostra ter, não constitui oportunidade para todo o grupo de pescadores profissionais, mas mera opção forçada de garantia de subsistência para alguns, num contexto onde tais garantias são cada vez mais escassas.

Uma das consequências desse processo é a sobrepesca, por exemplo, do Pacu (Piaractus mesopotamicus), que é um dos peixes mais visados pelos pescadores amadores e cuja captura vem diminuindo a uma taxa média aproximada de $18 \%$ ao ano, desde 1994, para o Estado de Mato Grosso do Sul (CATELLA, 2001). À revelia deste fato, outras espécies de peixe também têm sido predadas de forma intensiva.

Nesse viés, denota-se que o incremento da pesca amadora tem sido feito, em muitas ocasiões, de forma negligente à necessidade de conservação dos recursos naturais. Assim, boa parte do estoque pesqueiro foi abalada com o crescimento desordenado da movimentação de turistas atraídos pelos vastos rios piscosos do Pantanal Sul-Mato-Grossense. Tais turistas, em muitas ocasiões, também são responsáveis por exacerbado impacto sobre o ambiente no que tange à poluição dos rios e à construção de empreendimentos turísticos a eles destinados com o intento de atraí-los, exercendo pressão sobre os recursos naturais.

Face a esses fatos, houve, pois, a necessidade de se estipular meios que coibissem a prática negligente do turismo voltado à pesca amadora, de modo a se criar noções de sustentabilidade na gestão dos recursos naturais. Na visão de Ruschmann (1997) tais meios, ditos sustentáveis, viriam de encontro à prevenção dos impactos ambientais danosos do turismo, prolongando o ciclo de vida turístico de uma dada localidade.

Para atender a esses anseios foi criado, em 1994, O Sistema de Controle de Pesca do Mato Grosso do Sul (SCPESCA/MS), que teve como objetivo lograr uma caracterização geral da pesca no Pantanal Sul-Mato-Grossense, de modo a acumular informações que visem a identificar as principais tendências, tanto das espécies de peixes exploradas quanto dos aspectos sócio-econômicos da pesca. Esse sistema foi fruto de uma parceria entre o $15^{\circ}$ Batalhão de Polícia Militar Ambiental do Mato Grosso do Sul (15 BPMA-MS); A Secretaria de Estado e Meio Ambiente (SEMA-MS); e a EMBRAPA Pantanal, com seus estudos acerca da temática em voga.

Por meio das pesquisas da SCPESCA/MS (1994, 1995, 1996, 1997, 1998, 1999) constatou-se que a participação atual da categoria profissional está em torno de $20 \%$, ao passo que a da pesca amadora está em cerca de $80 \%$ do total de pescado extraído dos rios do Pantanal de Mato Grosso do Sul. Não obstante, em detrimento destes números expressivos acerca da pesca amadora, a prática de tal modalidade vem apresentando tendências de entrar em decréscimo nos próximos anos em virtude, sobretudo, de um maior rigor na fiscalização das especificidades do pescado obtido, em decorrência dos impactos danosos do crescimento desordenado deste setor. Nesse ínterim, Catella (2003) deixa claro que o número de pescadores esportivos (turistas) no Pantanal Sul vem diminuindo cada vez mais: 59 mil em 1999, 43 mil em 
2000, 35mil em 2001 e 30 mil em 2002.

Dentre os instrumentos para coibir a pesca amadora predatória estão, notadamente, a obrigatoriedade, pelo pescador, do porte de uma licença de pesca amadora, expedida pelo IBAMA, além de um maior rigor na fiscalização do tamanho do pescado extraído dos rios, do peso, bem como da necessidade de proibição da pesca em períodos de piracema. Essas ações já afugentaram alguns turistas, fazendo com que a economia da região se ressentisse da sua diminuição e dos conseqüentes gastos diretos e indiretos que, via de regra, eles têm.

Tais meios de fiscalização intensiva são cruciais, no que tange à pesca, para a conservação dos recursos naturais e reversão dos quadros de diminuição intensiva dos estoques de pescado nos rios do Pantanal Sul-Mato-Grossense, mantendo assim as atividades dos pescadores profissionais. Nesse sentido, vão de encontro à manutenção de uma manifestação cultural há tempos evidente na região, que é o fenômeno da pesca para os pescadores profissionais, que herdaram costumes e tradições de seus antepassados.

Deste modo, face à possível consolidação de uma situação de progressivo declínio da pesca amadora e do conseqüente desaquecimento do setor turístico pesqueiro no Pantanal, uma situação se apresenta como sendo de urgente reflexão: Como fomentar o turismo e, por conseguinte, os setores econômicos de Corumbá, que é a principal cidade do Pantanal de Mato Grosso do Sul, mesmo com o declínio da pesca amadora?

Esta resposta está, pois na diversificação dos produtos turísticos oferecidos pela cidade de Corumbá e na implementação do trade turístico da localidade. Tais fatos devem estar em consonância com o protagonismo dos interesses dos pescadores profissionais, que constituem um contingente significativo da população de Corumbá e apresentam exacerbada possibilidade de fomentar o Ecoturismo, que possui meios de expansão face às demandas atuais das sociedades contemporâneas, que anseiam por áreas verdes preservadas e por conhecimentos acerca de representações culturais as mais variadas possíveis.

Segundo MICT/MMA (BRASIL, 1994a), o Ecoturismo surge como um dos mais importantes instrumentos de viabilização econômica para o gerenciamento correto dos recursos naturais, oferecendo aos indivíduos uma alternativa digna de conquistar seu sustento e uma vida melhor, ao mesmo tempo em que assegura às gerações futuras, o acesso aos legados da natureza.

Desta feita, em face das questões delineadas, este trabalho tem como objetivo analisar o envolvimento dos pescadores profissionais na atividade do turismo, de modo a correlacionar os anseios desses grupos com a necessidade de fomento da atividade do Ecoturismo, que se faz urgente como instrumento de conservação dos recursos naturais, e apresenta-se como modalidade turística que possui vasta demanda e é passível de ser implantada na localidade analisada, gerando renda. 


\section{Descrição da Área e dos Sujeitos Analisados}

Corumbá é a principal e mais antiga cidade da porção oeste do estado de Mato Grosso do Sul, sendo porta de entrada para o Pantanal Sul-Mato-Grossense, razão pela qual foi apelidada de "capital do pantanal" (Figura 1). Esses fatores, aliados à contigüidade que o município exerce com o Paraguai e a Bolívia, formando uma espécie de grande rede urbana com quase 150 mil pessoas, faz com que o choque de culturas na localidade seja demasiadamente grande, o que pode ser utilizado como atrativo para turistas, além das belezas naturais da região (ITO, 2000).

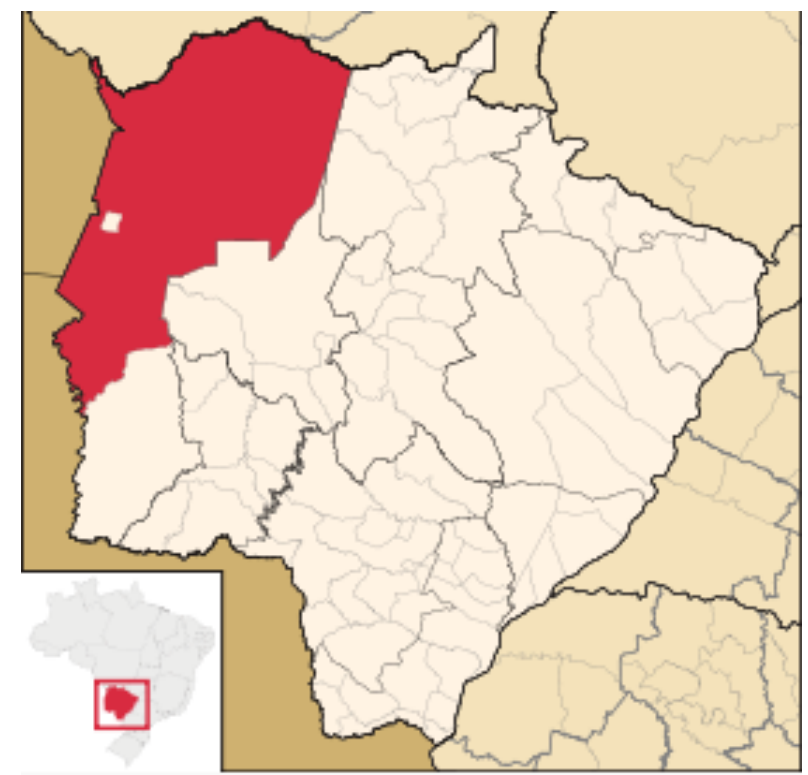

Figura 1: Localização Geográfica de Cidade de Corumbá, no Mato Grosso do Sul (Montagem de Raphael Lorenzeto de Abreu).

Ademais, conforme Ito (2000) Corumbá é a terceira cidade mais importante do estado em termos econômicos, culturais e populacionais, depois de Campo Grande (capital de Mato Grosso do Sul) e Dourados (segunda cidade mais importante). Apresenta um porto fluvial que serve como mecanismo de escoamento da produção extrativa da região, sobretudo de minérios, o que faz da cidade um relevante entreposto comercial através da possibilidade de navegação propiciada pelo Rio Paraguai, que margeia Corumbá e interliga a região aos demais países da extremidade sul da América do Sul e perfaz a fronteira entre Brasil, Bolívia e Paraguai.

Economicamente, a cidade destaca-se pelas atividades extrativas primárias, como a mineração e a pesca. Ademais, o setor de comércio e serviços é relevante, para atender à expressiva população urbana da região, que perfaz aproximadamente $90 \%$ da população absoluta, que é de cerca de 100 mil habitantes (OLIVEIRA; PINHEIRO; MICHELS; BRUM, 2008). 
O patrimônio arquitetônico da cidade também é extremamente peculiar, com construções que datam do século XVI, época do início da colonização da área. Existe até o chamado "casario do Porto", que engloba essas construções antigas que margeiam o rio Paraguai, e é alvo de ações de restauração para que preservem as características históricas originais (OLIVEIRA; PINHEIRO; MICHELS; BRUM, 2008).

No que tange, especificamente, aos pescadores profissionais, não se sabe ao certo o quantitativo de indivíduos que os representam, uma vez que estimá-los constitui em tarefa impraticável por razões técnicas que estão, sobretudo, na facilidade de se obter uma licença profissional de pesca, bem como no acesso à benefícios sociais, provenientes do governo, associados à condição de pescador em períodos de piracema. Porém sabe-se precisamente que são indivíduos que possuem baixa escolarização e residem, via de regra, nas margens do rio Paraguai (principal rio utilizado para a pesca), muitas vezes em condições precárias de vivência (SOUZA; JUNIOR; ÁVILA; MARTINS, 2004).

Não obstante, corroborando a importância que a pesca e, por conseguinte os pescadores apresentam para a economia da região de Corumbá, uma pesquisa efetuada pelo SCPESCA/MS (1999) constatou que a atividade pesqueira no Pantanal, seja em sua forma profissional ou amadora, no período de 1997 a 1999, contribuiu com uma geração de Receita Bruta média para a economia local no valor de $\mathrm{R} \$$ 168.426.291,66 anuais. Deduzidos os gastos intermediários realizados, ou seja, aqueles que não são internalizados na região, o estudo chegou a um valor agregado da atividade pesqueira correspondente a um montante médio de $\mathrm{R} \$ 116.084 .998,75$ anuais.

Para que se mensurasse o montante bruto resultante da atividade pesqueira profissional, utilizou-se o peso total de pescado extraído dos rios, registrado pelo SCPESCA/MS (1999), multiplicado pelo preço médio por quilo desses produtos no mercado, determinado pela oferta e pela existência de demandantes para os mesmos. Ressalte-se que, para que se chegasse na receita bruta resultante da atividade pesqueira amadora, lançou-se mão do valor médio total gasto por pescador durante sua estada em Corumbá, seja com hospedagem, alimentação, transporte local e demais subitens do trade turístico (excluídos, porém, os gastos de transporte e demais gastos do indivíduo até sua chegada em Corumbá).

Tomando-se como base o fato de que o PIB anual de Corumbá é de R\$ 1.973.945mil, segundo dados do IBGE de 2006, denota-se que a atividade pesqueira possui expressivo peso na consecução deste montante. Mesmo sendo os dados apresentados pelo SCPESCA/MS (1999) correspondentes aos anos de 1997 a 1999, é possível se ter uma idéia de que a atividade da pesca, com a geração de seus valores diretos e indiretos, não deve ser negligenciada.

É justamente neste cenário de provável intensificação da diminuição da atividade pesqueira amadora, com conseqüente redução da receita decorrente de tal modalidade turística, que Corumbá insere-se no escopo deste trabalho, compreendendo o lócus das pesquisas em voga, onde há urgência de se fomentar o turismo sustentável. 


\section{Ecoturismo e Desenvolvimento Sustentável}

A ecologia e a conservação do meio ambiente, a partir da década de 1970 , passam a ser um assunto amplamente discutido nos países desenvolvidos, dando início a um processo de sucessivos debates e encontros que culminaram em documentos como: a Declaração de Estocolmo (1972), a Declaração de Cocoyoc (1974), o Relatório Bruntland (1987), a Rio-92 e a Rio+10, todos com o intuito de abrir espaços para elaborar estilos alternativos de desenvolvimento que comportem as premissas básicas de um desenvolvimento sustentável.

Para a Comissão Mundial sobre o Meio Ambiente e Desenvolvimento - CMMAD (1988), o desenvolvimento sustentável é entendido como um "modelo de desenvolvimento econômico e social que atende às necessidades do presente sem comprometer a possibilidade de as gerações futuras atenderem às suas próprias necessidades".

O desenvolvimento sustentável surge, assim, como uma forma de conciliar o desenvolvimento econômico, a preservação do meio ambiente e a valorização cultural das comunidades que o praticam. Desta feita, pauta-se no protagonismo das comunidades, com suas especificidades garantidas e preservadas, resguardando também as características do local em que residem.

Dentro desse viés, é inegável que o turismo, dadas as suas especificidades, apresenta-se como um meio de se chegar aos níveis de desenvolvimento sustentável de uma dada localidade. No momento atual, ressalte-se que o turismo surge como sendo extremamente relevante, quer como elemento que satisfaz parte de uma das necessidades básicas atuais e mais pujantes do homem, que é o lazer; quer como atividade comercial e industrial geradora de divisas econômicas, que têm grande peso em diferentes formações sócio-econômicas.

As áreas naturais, sua paisagem, fauna, flora e seus elementos culturais constituem grandes atrações, tanto para os habitantes dos países aos quais as áreas pertencem, como para os turistas de todo o mundo.

Atualmente a natureza possui, sem dúvidas, grande valor comercial, decorrência do acelerado processo de degradação ambiental e aumento das concentrações urbanas, que, utilizam o meio ambiente natural como forma de lazer.

A deterioração dos ambientes urbanos pela poluição sonora, visual e atmosférica, a violência, os congestionamentos e as doenças provocadas pelo desgaste psicofísico das pessoas são as principais causas da 'fuga das cidades' e da 'busca do verde' nas viagens de férias e de fim de semana (RUSCHMANN, 1997: p.9). 
O turismo é, em suas diversas modalidades, o tipo de desenvolvimento que tende a modificar rapidamente a situação social e econômica das comunidades, com impactos tanto positivos quanto negativos (LINDBERG \& HAWKINS, 1995:223).

Lage e Milone (2000) recomendam que o desenvolvimento sustentável de atrativos turísticos ocorra em etapas, em áreas distintas e de extensão territorial menor, permitindo, assim, a implantação de forma gradual, favorecendo o acompanhamento e o controle de sua evolução.

De acordo com Ruschmann (1997), é preciso concentrar os esforços em um desenvolvimento sustentável, não apenas de patrimônio natural, mas também dos produtos que se estruturam sobre todos os atrativos e equipamentos turísticos, para prevenir os impactos ambientais do turismo, a degradação dos recursos e a restrição do seu ciclo de vida.

Neste contexto, o turismo sustentável surge como uma das formas para se alcançar o desenvolvimento sustentável de uma região, evitando danos ao meio ambiente, minimizando os custos sociais que afetam os moradores das localidades, otimizando os benefícios do desenvolvimento do turismo.

Para Pearce (apud BENI, 1998: p.61), turismo sustentável é a

[...] maximização e otimização da distribuição dos benefícios do desenvolvimento econômico baseada no estabelecimento e na consolidação das condições de segurança sob as quais são oferecidos os serviços turísticos, para que os recursos naturais sejam mantidos, restaurados e melhorados.

Da mesma forma que o turismo pode manter ou melhorar as condições de uma localidade, se praticado sem planejamento adequado, também pode alterar rapidamente uma área até inviabilizar a prática do turismo.

O desenvolvimento rápido e descontrolado do turismo em localidades com recursos naturais com excepcional beleza, muitas vezes únicos, provoca excesso da demanda e superdimensionamento da oferta, que descaracterizam a paisagem e fazem a destinação perder as características que deram origem à atratividade (RUSCHMANN, 1997: p.116).

Em decorrência do crescimento do turismo em áreas naturais, proveniente da "busca pelo verde" e da "fuga" dos grandes centros urbanos, conforme expôs Ruschmann (1997), o Ecoturismo surge como um novo segmento do turismo, destacando-se como uma nova fonte de renda, demonstrando, ainda, preocupação com a conservação do meio ambiente e da cultura das comunidades locais.

A necessidade de fuga ao estilo de vida 'urbano', a procura de locais mais saudáveis e a conscientização das pessoas relativamente aos 
problemas do ambiente, fizeram nascer o Ecoturismo e com ele a busca pela valorização intelectual, locais de características únicas e de elevada sensibilidade cultural e ecológica (BRASIL, 1994a: p.5).

O Ecoturismo representa uma ruptura com a tradicional fórmula turística: sol, mar e areia. Ele convida à aventura, oferecendo oportunidades de aprendizado e de conservação, incitando uma experiência espiritual com a natureza (LINDBERG; HAWKINS, 1995: p.207).

De acordo com Pires (1998), o Ecoturismo expressa um segmento do turismo que se apresenta hoje como uma das principais alternativas para o desenvolvimento sustentado nos destinos turísticos do mundo, em especial em regiões e países de economia deprimida.

Para Lindberg e Hawkins (1995), é considerado como um novo e promissor instrumento para preservar áreas naturais frágeis e ameaçadas, quanto um meio para propiciar oportunidades para o desenvolvimento das comunidades dos países emergentes.

[...] o Ecoturismo, desenvolvido dentro dos seus princípios conceituais e tendo ampliada sua abrangência para além da proteção do meio físico, constitui-se em um fator de sustentabilidade dos meios visitados, não só a partir da conscientização ambiental de um "novo turista", mas também do envolvimento sócio-cultural e econômico das comunidades receptoras no processo de desenvolvimento da atividade (RUSCHMANN, 2000: p.21)

A atividade ecoturística apresenta, notadamente, aspectos diferenciados dos demais segmentos do turismo, principalmente do turismo de massa. Segundo Pires (1998:54), os principais diferenciais do Ecoturismo, são:

- Atrai um segmento da demanda motivado pela natureza e por originalidades culturais;

- Busca o diferente; o não convencional;

- Pouca gente distribuída em muitos destinos;

- Adaptação do turista aos destinos visitados;

- Preocupação com os impactos ambientais;

- Tratamento personalizado aos clientes;

- Monitoramento constante das atividades desenvolvidas;

- Preocupação com a formação e capacitação dos guias, operadores e fornecedores. 
Também podem ser aspectos diferenciadores da atividade ecoturística: a educação ambiental para o turista e para a comunidade local, o planejamento integrado, com preferência à regionalização, manejo e administração verde do empreendimento e a "consciência ambiental" de seus praticantes. O Ecoturismo é subdividido por Pires (1998: p.55) em alguns segmentos (Tabela 1):

Tabela 1: Caracterização dos tipos e as atividades do Ecoturismo segundo Pires (1998: p.55).

\begin{tabular}{|c|c|}
\hline $\begin{array}{l}\text { TIPOS DE } \\
\text { ECOTURISMO }\end{array}$ & ATIVIDADES ECOTURÍSTICAS \\
\hline Ecoturismo Científico & $\begin{array}{l}\text { Estudos e pesquisas científicas em botânica, ar- } \\
\text { queologia, paleontologia, geologia, zoologia, bio- } \\
\text { logia, ecologia, antropologia, espeleologia etc. }\end{array}$ \\
\hline Ecoturismo Educativo & $\begin{array}{l}\text { Observação da vida selvagem (fauna e flora), in- } \\
\text { terpretação da natureza, orientação geográfica, } \\
\text { observação astronômica. }\end{array}$ \\
\hline $\begin{array}{c}\text { Ecoturismo Lúdico e } \\
\text { Recreativo }\end{array}$ & $\begin{array}{l}\text { Caminhadas, acampamentos, contemplação da } \\
\text { paisagem, banhos e mergulhos, jogos e brinca- } \\
\text { deiras, convivência e sociabilidade, "pesca", pas- } \\
\text { seios montados, passeios em embarcações, ci- } \\
\text { cloturismo. }\end{array}$ \\
\hline Ecoturismo de Aventura & $\begin{array}{l}\text { "Trekking", montanhismo, expedições, contato } \\
\text { com culturas remotas, exploração de lugares e } \\
\text { ambientes inóspitos e desconhecidos, etc. }\end{array}$ \\
\hline Ecoturismo Esportivo & $\begin{array}{l}\text { Escalada, canoagem, "rafting", "canyoning", mer- } \\
\text { gulho, "montain bike", "paragliding", bóia "cross", } \\
\text { "surf", rappel, balonismo, vôo livre, etc. }\end{array}$ \\
\hline Ecoturismo Étnico & $\begin{array}{l}\text { Contatos com integração cultural do ecoturista } \\
\text { com populações autóctones (primitivas/nativas) } \\
\text { que vivem em localidades remotas em estreita } \\
\text { relação com a natureza. }\end{array}$ \\
\hline Ecoturismo Natur & $\begin{array}{l}\text { Prática do "nudismo" ao ar livre em ambientes } \\
\text { naturais. }\end{array}$ \\
\hline
\end{tabular}

O Ecoturismo é, portanto, um segmento muito abrangente, que atinge diferentes tipos de clientes com perfis e motivações bem diferenciados. Neste segmento, diversos nichos de mercado são identificados, como, por exemplo, a observação de pássaros e o contato com culturas peculiares.

Num esforço para classificar as características das pessoas interessadas pela atividade ecoturística, Budowisk (apud PIRES, 1998), propôs a seguinte tipologia: 
Ecoturistas cientistas e estudiosos: necessidade de pesquisa, treinamento ou ensino em áreas naturais. Permanecem longos períodos no local do estudo;

Ecoturistas naturistas forte: fazem da natureza o principal motivo para a realização da viagem. São observadores de aves, orquídeas etc. Não são muito exigentes em relação à acomodação a eles dispendida, ao passo que cobram muito as informações acerca da área visitada;

Ecoturistas naturistas suave: viaja para observar a fauna, a flora, a paisagem e o modo de vida local. Requer melhor infra-estrutura de acomodação do que o ecoturista naturista suave e realiza atividades menos intensas na natureza. A nível mundial é o segmento que mais cresce;

Ecoturistas de aventura: sua permanência na natureza está ligada a prática de algum esporte, como a caminhada, montaria, ciclismo, mergulho, canoagem etc. Tal atividade encontra-se em grande desenvolvimento no Brasil face às possibilidades e recursos naturais vastos que este país, em geral, apresenta.

A determinação da capacidade de carga de uma localidade é de fundamental importância para que o planejamento de fomento da atividade turística não venha comprometer e colocar em risco os atrativos naturais e culturais da localidade receptora.

A fragilidade dos ecossistemas naturais, muitas vezes, não comporta um número elevado de visitantes e, menos ainda, suporta o tráfego excessivo de veículos pesados. Por outro lado, a infra-estrutura necessária, se não atendidas as normas pré-estabelecidas, pode comprometer de maneira acentuada o meio ambiente, com alterações na paisagem, na topografia, no sistema hídrico e na conservação dos recursos naturais florísticos e faunísticos. O alojamento das populações locais se configura, também, como outro risco, pois a presença de operadores, quase sempre sem nenhuma relação orgânica com a região, pode gerar novos valores incompatíveis com os comportamentos locais (BRASIL, 1994a: p.17).

O manual de Ecoturismo define a capacidade de carga de uma determinada área como "uma medida do número de indivíduos de uma espécie que o ambiente consegue suportar, sendo o limite ambiental imposto ao crescimento de uma população" (BRASIL, 1994b). Para Boo (apud Ruschmann, 1997), a capacidade de carga de um recurso turístico é o número máximo de visitantes (por dia/mês/ano) que uma área pode suportar, antes que ocorram alterações nos meios físico e social.

Beni (1998: p.61) define capacidade de carga como:

[...] número máximo anual de visitantes que o atrativo turístico natural pode suportar, sem sofrer alterações, considerando-se o equilíbrio di- 
nâmico entre ambiente, quantidade de turistas e qualidade dos serviços instalados.

No processo de determinação da capacidade de carga de uma área, é necessário levar-se em consideração algumas variantes. Ruschmann (1997: p.116) diz que

[...] essa capacidade, porém, depende do tipo e do tamanho da área, do solo, das topografias, dos hábitos das pessoas e da vida selvagem (animais), bem como do número e da qualidade dos equipamentos instalados para atender aos turistas.

Corumbá, face às características já elucidadas, apresenta indelével potencial para fomentar a atividade ecoturística, uma vez que abarca, em seu vasto território, boa parte do complexo do Pantanal, que é um dos ecossistemas mais ricos e diversificados do planeta; possui rico patrimônio histórico-arquitetônico, dado que foi uma das primeiras cidades fundadas no estado de Mato Grosso do Sul, com os primeiros resquícios de vida urbana datados do início do século XVI; além de apresentar vasto patrimônio cultural, evidenciado pelas inter-relações de grupos sociais os mais distintos possíveis, provenientes também da Bolívia e do Paraguai.

No que tange à capacidade de carga, Corumbá conta, fisicamente, com infraestruturas básicas, como: um aeroporto, onde se encontra um centro de atendimento ao turista; rede hoteleira com 44 empreendimentos localizados na área urbana, 39 empreendimentos localizados na área rural e 48 barcos-hotel que somados oferecem 3.946 leitos; 22 agências de turismo devidamente cadastradas no Ministério do Turismo; 40 empreendimentos de alimentação (contabilizando bares e restaurantes); um pavilhão de exposições e feiras; um teatro; e um centro de convenções em fase de construção (SMTUR, 2003).

Não obstante, o turismo, especialmente o de pesca, praticado na região com base nas infra-estruturas supracitadas negligencia a capacidade de carga ambiental, fato este corroborado pela queda nos estoques de pescado dos rios do Pantanal SulMato-Grossense. Isso exige, pois, medidas que possam coibir tal fato, o que dá um prospecto de diminuição da pesca amadora e conseqüente redução do aporte de renda na cidade de Corumbá.

Neste contexto é que os pescadores profissionais se inserem. Constituem um grupo tradicional na região de Corumbá, abarcando grande contingente de pessoas que, direta ou indiretamente, sofrerão com o desaquecimento do setor do turismo de pesca. Iniciativas devem se propostas para atender aos anseios desse grupo, em concomitância ao desenvolvimento sustentável da cidade. O turismo sustentável mostra-se, pois, relevante para o desenvolvimento sustentável de Corumbá. Assim, conhecer a relação que os pescadores profissionais estabelecem, ou que podem estabelecer com esta modalidade turística mostra-se como sendo de fundamental importância. 
Sabe-se que, para esses indivíduos, a pesca representa a evidência de uma manifestação cultural, herdada há tempos por gerações diversas. Não se pretende, pois, deslocar esses indivíduos de suas lides quotidianas e de suas manifestações típicas, mas aproveitá-los, com suas especificidades resguardadas, na atividade do turismo sustentável, que apresenta maior valor agregado em comparação à pesca e pode ser um importante meio de conservação dos recursos naturais e geração de renda para os pescadores que, via de regra, carecem de condições que lhes propiciem melhora em sua qualidade de vida.

\section{PROCEDIMENTOS METODOLÓGICOS}

O surgimento do problema que norteou este estudo foi fruto de intensas pesquisas bibliográficas acerca da temática da pesca no Pantanal Sul-Mato-Grossense. Face ao amplo fragmentário teórico pesquisado e conforme já foi discorrido na parte introdutória deste trabalho, constatou-se a necessidade de conservar os recursos naturais e culturais da região em virtude dos impactos crescentes sobre o meio ambiente decorrentes do aumento vertiginoso e desordenado da pesca amadora.

A criação de diretrizes que visam ao acirramento da fiscalização do pescado extraído dos rios veio de encontro a essa questão, sobretudo após os estudos elucidatórios da SCPESCA/MS (1994, 1995, 1996, 1997, 1998 e 1999). Porém, em face de um maior rigor das bases para a efetivação da pesca amadora, há prospectos que dão conta de uma permanente retração desse segmento turístico, o que abala a economia da região, sobretudo de Corumbá, que é a principal cidade da área.

Desta feita, houve a necessidade de se fomentar o turismo da região, sobretudo em sua forma sustentável, preservando os recursos existentes, sejam naturais ou culturais. Um indelével meio para isso, notadamente, é subsidiar o protagonismo dos pescadores profissionais, que perfazem expressivo contingente da população de Corumbá e encontram-se ressentidos com o prospecto de diminuição da atividade da pesca amadora.

Porém, há que se conhecer os anseios e especificidades dos pescadores profissionais para que se proponham iniciativas mais pontuais de inserção destes indivíduos na atividade do Ecoturismo.

Desta feita, a insuficiência de dados e informações bibliográficas referentes ao Ecoturismo em Corumbá, aliada à preocupação em verificar o perfil dos pescadores profissionais em relação à atividade turística obrigaram a realização de pesquisa de campo, que consistiu na aplicação de questionários semi-estruturados aos pescadores de alguns locais da cidade de Corumbá, como os bairros Cervejaria, Universitário e Borroski, ambos na orla portuária corumbaense. Tal pesquisa teve o apoio financeiro e respaldo em sua consecução da Fundação de Apoio ao Desenvolvimento do Ensino, Ciência e Tecnologia do Estado de Mato Grosso do Sul (FUNDECT/MS). 
Foram aplicados, pois, 300 questionários, entre os anos de 2006 e 2007, com os pescadores profissionais de Corumbá, onde foram apuradas as seguintes questões: Se os indivíduos possuem outra fonte de renda, fora a pesca profissional; o tempo em que residem em Corumbá; o tempo em que já trabalham com a pesca profissional; a faixa etária dos indivíduos; a percepção que têm acerca da atividade turística; se pertencem a alguma cooperativa ou associação; a capacitação que tiveram para desenvolver algumas atividades específicas; o interesse que têm em se capacitar para desenvolver alguma atividade voltada ao turismo; se já, em alguma oportunidade, trabalharam com a atividade turística, bem como com quais atividades trabalhou; o interesse que têm em trabalhar com a atividade turística, e quais atividades gostaria de desenvolver; os lugares turísticos da cidade de Corumbá que conhecem; sua opinião acerca do trade turístico da cidade; sua opinião com relação aos benefícios oriundos do fomento da atividade turística; sua opinião acerca dos principais atrativos que a cidade fornece; o posicionamento do poder público quanto ao fomento da atividade turística; e, por fim, as atividades que desenvolvem nas horas de lazer.

Tais indagações permitiram que se criasse um perfil dos pescadores profissionais da cidade de Corumbá, demonstrando seus principais anseios e as atividades que desenvolvem. As perguntas não tencionaram concluir a questão da pesca ou do turismo de pesca, servindo apenas como direcionador nas reflexões acerca do fomento da atividade do turismo sustentável e da necessidade de atendimento dos anseios dos pescadores profissionais.

É preciso citar que os questionários aplicados obedeceram a amostra não probabilística, uma vez que não se tinha noção exata do efetivo número de pescadores da cidade. Porém, isto não macula as constatações deste trabalho, uma vez que, segundo Panosso-Netto (2005: p.117), "uma pesquisa qualitativa e humanista está interessada num aprofundamento das respostas obtidas e não no número de questionários aplicados".

Quanto aos meios de aplicação dos questionários, procurou-se aplicá-los em grupos, uma vez que se tinha um levantamento prévio dos principais bairros da cidade de Corumbá onde os pescadores residiam e desenvolviam suas atividades, logo, já se sabia onde se aglomeravam, facilitando as tarefas do pesquisador. Nos locais onde se encontravam mais de um pescador, ambos eram pesquisados em concomitância, uma vez que, nesses casos, procurava-se destinar um pesquisador para cada sujeito a ser pesquisado, de modo a se obter a resposta imparcial de cada um deles, e não opiniões esparsas e emitidas em conjunto.

No que tange à seleção dos indivíduos a serem pesquisados, procurou-se abordar todos aqueles que se diziam pescadores e/ou que viviam da pesca. Assim, muitas das vezes abordava-se o indivíduo em sua lide diária, quando chegavam da pesca ou quando estavam dirigindo-se ao rio, o que corroborava a constatação de que eram, realmente, pescadores profissionais. Destaque-se, porém, que não havia embasamento estatístico acerca dos indivíduos a serem pesquisados, dado que o objetivo central da pesquisa era um aprofundamento nas questões humanistas e qualita- 
tivas acerca da pesca e dos pescadores.

Não obstante, a despeito dos aspectos qualitativos inerentes à pesquisa em voga, adotaram-se também certos critérios quantitativos em sua realização, uma vez que procedeu-se ao tratamento estatístico dos questionários aplicados, com vistas ao alcance dos objetivos delineados. Portanto, a pesquisa teve caráter qualitativo e quantitativo.

Foi também de fundamental importância a observação participante dos pescadores profissionais em seu local de vivência, bem como em sua lide diária de trabaIho. Tais fatos, em concomitância às respostas oriundas dos questionários, dão conta de melhores subsídios para se identificar os anseios desses indivíduos, bem como as possibilidades que apresentam em se integrar a atividade do turismo em sua forma sustentável.

\section{RESULTADOS}

\section{Análise das Relações dos Pescadores Profissionais de Corumbá com a Ativida- de Turística Sustentável}

Vários foram os resultados alcançados que, para melhor entendimento, optouse por dividir em critérios de avaliação, que foram atinentes às seguintes temáticas, essenciais para a estipulação de um perfil dos pescadores profissionais: fonte de renda; tempo de residência em Corumbá/MS; período de tempo que trabalha com a pesca; faixa etária; percepção da atividade turística; associativismo; capacitação de mãode-obra; experiências de trabalho com a atividade turística; recursos que atraem os turistas; benefícios para a cidade com o fomento do turismo; atuação do poder público quanto a iniciativas de promoção do turismo; e as formas de lazer da cidade. Os resultados obtidos são discorridos nos tópicos seguintes.

\section{Fonte de Renda}

O primeiro item analisado durante as pesquisas diz respeito à fonte de renda dos pescadores profissionais que residem Corumbá (Figura 2). Os dados revelam que grande parte dos indivíduos (64\%) não possui outras fontes de renda senão a pesca profissional. Ademais, somente no período de Piracema, quando a pesca é proibida nos rios do Pantanal Sul, é que alguns fazem o que eles chamam de bico, ou seja, pequenos serviços como pedreiros, pintores e ajudantes, para aumentar a renda doméstica, mostrando assim que $36 \%$ possuem outra fonte de renda.

No período da Piracema, cada família de pescadores é assistida de salário mínimo e cesta básica de alimentos, subsidiados pelo Poder Público. Porém, segundo muitos pescadores, há demasiada burocracia no cadastro para o recebimento desses benefícios que, na maioria das vezes, demoram a ser entregues ou em muitos casos nem o são. 


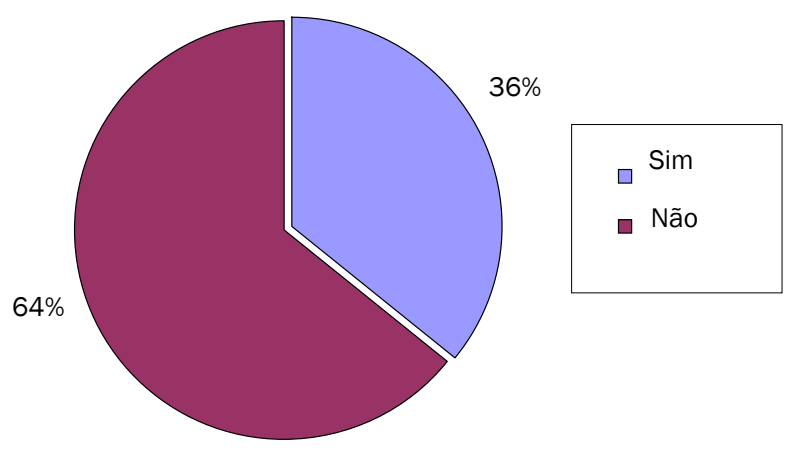

Figura 2: Constituição da Renda dos Pescadores Profissionais de Corumbá.

Não obstante, muitos pescadores relatam casos de indivíduos que obtiveram a licença para pesca profissional, obrigatória para aqueles que se destinam a essa atividade, e passaram a receber os auxílios governamentais em época de piracema, mas que não se destinam com regularidade a esta atividade. Isso demonstra o porquê há certa impossibilidade de se estimar o número efetivo de pescadores que desenvolvem suas atividades na região; bem como demonstra imperfeições da política de pesca adotada.

A constatação de que somente $36 \%$ dos pescadores se destinam a outra atividade, em períodos de piracema, com o escopo de complementar a sua renda auferida demonstra certa passividade e leniência desses indivíduos, que se mostram, de certa maneira, acomodados à ajuda governamental que percebem. Desta forma, negligenciam as possibilidades que podem advir de sua destinação temporária, por exemplo, à atividade turística.

Ademais, daqueles que se ocupam em outras tarefas, há a evidência de subemprego, uma vez que se destinam a atividades com possibilidades de remuneração inferior àquela que poderia advir das atividades do Ecoturismo, por exemplo.

Ressalte-se que não se faz aqui qualquer consideração acerca do banimento do auxílio que os pescadores recebem em períodos de piracema. Muito pelo contrário. Ele é essencial para que os profissionais garantam sua subsistência e mantenham-se afastados da pesca durante o período de reprodução e reorganização dos estoques de pescado. Apenas se discute, nesta oportunidade, a possibilidade de integração que os pescadores podem ter na atividade do Ecoturismo nesse tempo ocioso, o que não se evidencia na atual conjuntura. 


\section{Tempo de Residência em Corumbá}

No que tange ao tempo em que os pescadores profissionais pesquisados residem em Corumbá, o resultado dos questionários revelou que $92 \%$ moram na cidade há mais de dez anos (Figura 3). Isso demonstra, pois, que a atividade em voga é extremamente tradicional na região, e é praticada por indivíduos muitas vezes nascidos na própria localidade e que, assim sendo, a conhecem profundamente.

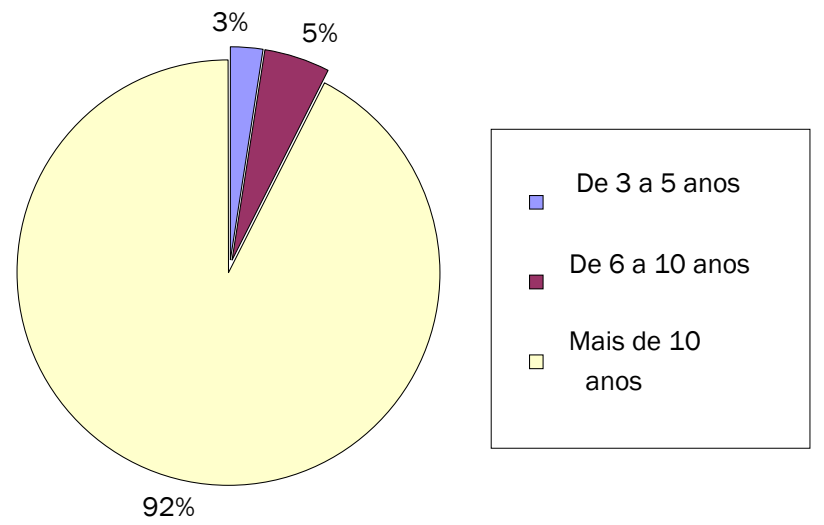

Figura 3: Tempo de Residência dos Pescadores Profissionais em Corumbá.

Esse conhecimento popular é que perfaz um indelével produto atrativo para algumas modalidades do Ecoturismo, sobretudo para aquela praticada pelos chamados ecoturistas naturistas fortes, na classificação de Budowisk (apud Pires, 1998).

Ademais, a evidência de que a pesca é praticada há tempos por uma gama de indivíduos corrobora a questão de que esta atividade é uma manifestação cultural da localidade e que, assim sendo, constitui um produto típico da mesma. Segundo Benevides (2003) é isso que atrai os turistas, uma vez que estes sujeitos tencionam conhecer aquilo que é típico de uma região, não por ser diferente, mas por ser autêntico e, desta feita, caracterizar um local.

\section{Período de Tempo que Trabalha com a Pesca}

Analisados os questionários, apurou-se que $75 \%$ dos pescadores trabalham com a pesca há mais de dez anos. Comparando este item com o que foi analisado supracitadamente, na Figura 3 (tempo de residência em Corumbá), em que 92\% responderam "há mais de dez anos", observou-se uma diferença de $17 \%$ referente a pescadores que moravam em outra cidade ou, mesmo morando na cidade há mais de dez anos, praticavam outra atividade econômica diferente da pesca (Figura 4). 
Um aspecto que merece ser ressaltado neste tópico diz respeito ao fato de que são poucos os indivíduos que se dizem "pescadores profissionais" há menos de dez anos (apenas 25\%), o que corrobora a constatação do aspecto tradicional e cultural que a pesca apresenta.

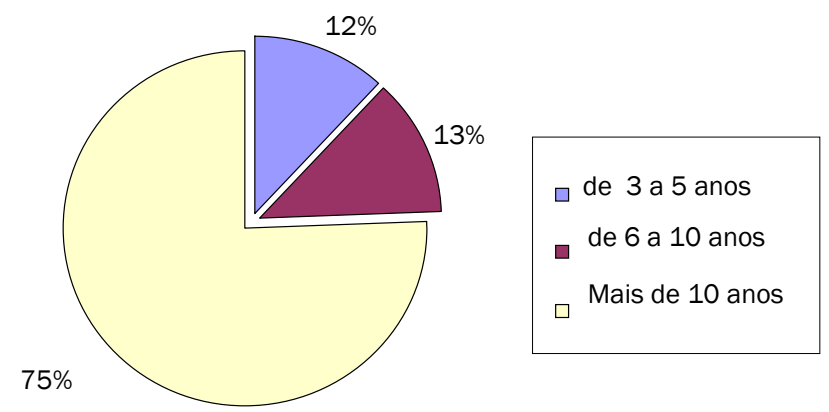

Figura 4: Tempo de Trabalho com a Pesca Profissional.

\section{Faixa Etária dos Indivíduos que Trabalham com a Pesca}

Constatou que $28 \%$ dos pescadores profissionais possuem mais de 50 anos de idade; 49\% possuem de 31 a 49 anos; ao passo que aproximadamente 23 \% têm entre 16 e 30 anos. Isso mostra que a pesca é realizada por indivíduos de meia-idade, sendo que o contingente de pessoas com idade mais avançada (de 50 anos para frente) também é expressivo (Figura 5).

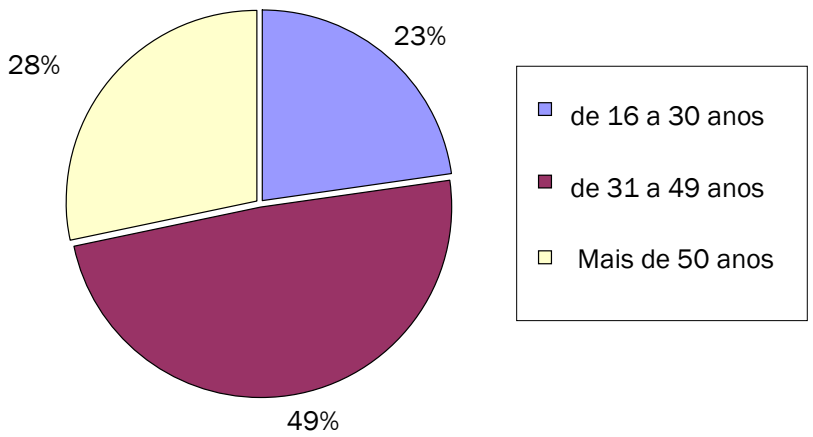

Figura 5: Faixa Etária dos Indivíduos que Trabalham com a Pesca em Corumbá. 
Porém, denota-se um decréscimo dos novos indivíduos que se destinam à pesca profissional, uma vez que $23 \%$ dos pescadores pesquisados possuem entre $16 \mathrm{e}$ 30 anos.

Sabe-se que a pesca, notadamente, é realizada por indivíduos com baixa escolarização. Contemporaneamente, em face de uma maior democratização do acesso ao ensino, há um decréscimo do número de pessoas que se destinam a atividade pesqueira em virtude da existência de oportunidades de melhor geração de renda com a realização de alguns anos de estudo.

\section{Percepção da Atividade Turística}

No que diz respeito à questão sobre o que o pescador entende e no que ele traduz a atividade turística, encontrou-se que $12 \%$ revelaram que é o Pantanal, $19 \%$ Progresso, 14\% Pesca Esportiva e mais da metade, 55\%, revelaram que é Fonte de Renda (Figura 6).
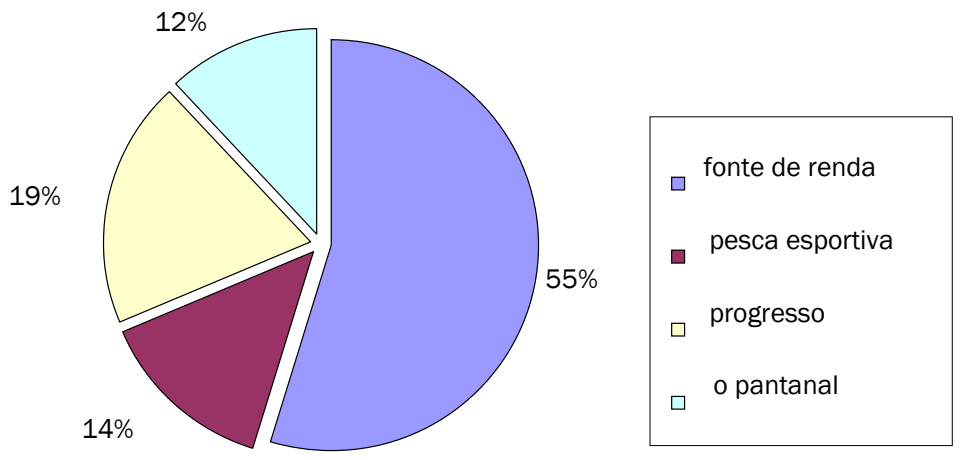

Figura 6: Percepção da Atividade Turística.

Desta feita, denota-se que o aspecto mais notável da atividade do turismo, na visão dos pescadores profissionais pesquisados, é a geração de renda que dela pode advir. Ademais, correlacionando esta constatação com a concepção de progresso que o turismo tem para $19 \%$ dos entrevistados, infere-se que o desenvolvimento sustentável é uma possibilidade viável para região, uma vez que engloba geração de renda, conservação ambiental e progresso humano, conceitos estes arraigados já no sensocomum dos pescadores.

Assim sendo, o Ecoturismo surge no conceito dos pescadores. Eles já conhecem as possibilidades e vantagens desta modalidade de turismo, de modo que já concebem a localidade onde residem como receptáculo dessa atividade. 


\section{Associativismo}

Dos pescadores que foram alvo da pesquisa em Corumbá, $72 \%$ afirmaram pertencer a alguma associação e/ou cooperativa que tem como escopo a luta e a observância de seus anseios (Figura 7). Porém, a despeito deste expressivo quantitativo de adeptos do associativismo, constatou-se que não raro tais entidades indispõem de oportunidades, capacitações e políticas de beneficiamento para seus sócios, que ficam a margem da possibilidade de ganho com a constituição de cooperativas.
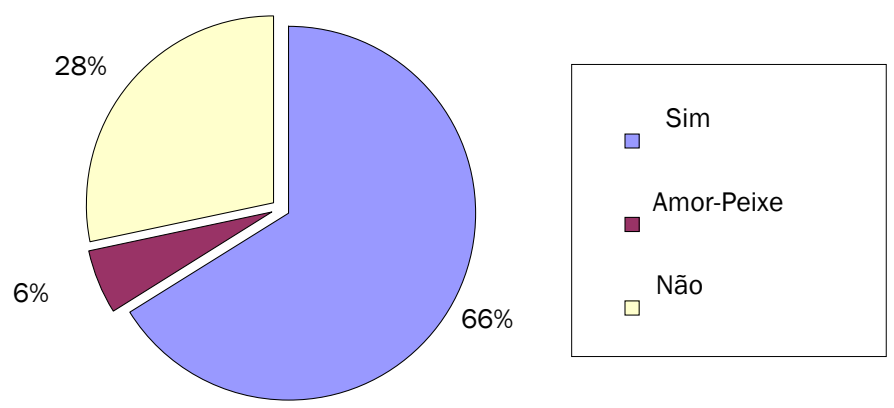

Figura 7: Composição dos Pescadores Profissionais de Corumbá que Pertencem a Alguma Cooperativa.

Dentre as associações que mais se destacam no atendimento aos anseios do grupo de pescadores, está a Associação de Mulheres Organizadas Reciclando o Peixe (Amor-Peixe), que trabalha com artesanatos a base de subprodutos do pescado, como o couro; além dos projetos sociais do Instituto Homem Pantaneiro (IHP), que é uma ONG que desenvolve trabalhos junto a indivíduos de baixa renda de Corumbá, dentre eles os pescadores, que dispõem de algumas oficinas de artesanato e culinária no local, a fim de capacitá-los para desenvolverem outras atividades além da pesca.

Porém, constatou-se que são escassas as iniciativas que visam a organizar os pescadores e, não obstante, tais iniciativas advêm de certas instituições de Corumbá, e não do próprio grupo de pescadores. Assim, é gritante a necessidade de organização desses sujeitos por iniciativas endógenas, ou seja, do próprio grupo, uma vez que ninguém mais do que eles conhecem os problemas e aspirações da comunidade.

Percebeu-se, durante a observação participante dos indivíduos decorrente da pesquisa de campo, a existência de certo revanchismo e de conflitos entre os pescadores, uma vez que cada um anseia capturar o maior número de peixes, e se ressentem, sobretudo com os outros pescadores, quando não logram êxito nessa empreitada. Isso atravanca, notadamente, iniciativas de organização desse grupo. 
Tal problemática poderia ser solucionada por meio da identificação de uma liderança nata dentro da comunidade, a qual teria o escopo de minorar os conflitos endógenos da mesma, solidarizando o sentimento de companheirismo que deve ser a tônica de iniciativas de associativismo.

Ressalte-se, por fim, que o associativismo, como ramo mais notável de políticas de promoção de Economia Solidária, é um excelente instrumento para o fomento de iniciativas de desenvolvimento sustentável, uma vez que reúne indivíduos em prol de objetivos comuns, quais sejam a observância de seus anseios e o fomento e conservação dos recursos, sejam naturais, históricos ou culturais, da localidade onde residem.

\section{Capacitação de mão-de-obra}

Quanto ao número de pescadores que já participou de alguma capacitação para exercer algum tipo de atividade mais especializada, o percentual é de apenas $18 \%$ do total entrevistado. Dessa parcela, $37 \%$ foram capacitados como piloteiros (guiadores de barcos), 18\% como guias de pesca, 13\% em cozinha (cozinheiros e ajudantes de cozinha) e $32 \%$ fizeram cursos de atendimento ao público no SEBRAE (Serviço Brasileiro de Apoio às Micro e Pequenas Empresas). Ao final, soma-se um total de $75 \%$ de pescadores que nunca participaram de nenhum tipo de capacitação (Figuras 8 e 9).
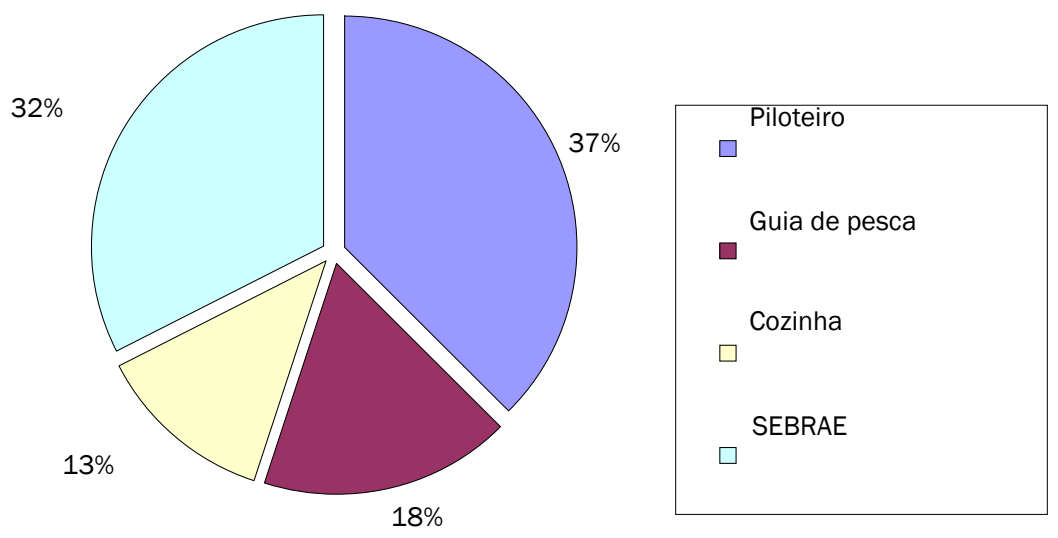

Figura 8: Configuração da Qualificação dos Pescadores Profissionais. 

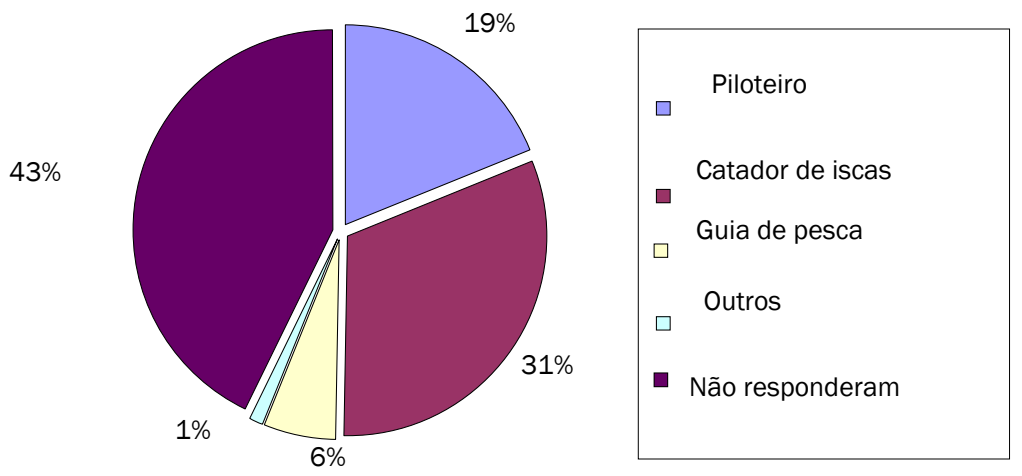

Figura 9: Percentual dos Pescadores que Tencionam Participar de Cursos de Qualificação.

Não obstante, à revelia deste expressivo contingente de pescadores que jamais participaram de programas de capacitação, observa-se crescente interesse por parte das comunidades para especializarem-se em algum segmento que lhes propiciem melhores rendas.

Neste viés, o turismo entra com demasiada importância na percepção dos pescadores, que revelam vontade extremamente grande em participar de cursos voltados a este segmento, que se mostra potencialmente atrativo no que tange à geração de melhores rendas.

Segundo os dados da pesquisa, $72 \%$ dos pescadores gostariam de participar de cursos de capacitação voltados à atividade turística. Confrontando esta constatação com a percepção que têm acerca da atividade turística sustentável na região, conforme relatado no tópico anterior observa-se, pois, a vontade que os pescadores apresentam de se integrarem ao Ecoturismo.

Ressalte-se também que a constatação de um pequeno contingente que participou de algum tipo de especialização para exercer alguma atividade mais específica é fruto do caráter artesanal que a pesca ainda apresenta na região do Pantanal SulMato-Grossense, não sendo vista como atividade econômica que requer treinamento e bons instrumentos para sua efetivação.

\section{Experiências de Trabalho na Atividade Turística}

Os resultados obtidos revelam que grande parte dos pescadores profissionais possui grande afinidade com atividades ligadas ao turismo, mostrando que a maioria, de alguma forma, já esteve atrelada, profissionalmente, ao turismo e têm conhecimento da importância da atividade para o município.

Considerável parte dos pescadores profissionais que já trabalharam com o turismo, que corresponde a $62 \%$ dos pesquisados, prestou os seguintes serviços: 
Piloteiro (19\%); Catador de Isca (31\%); Guia de Pesca (6\%); Outros Serviços (1\%), revelando que as atividades ligadas diretamente a pesca são as que mais abarcam os pescadores profissionais, em virtude, sobretudo, das crescentes demandas dos turistas (Figuras 10 e 11).
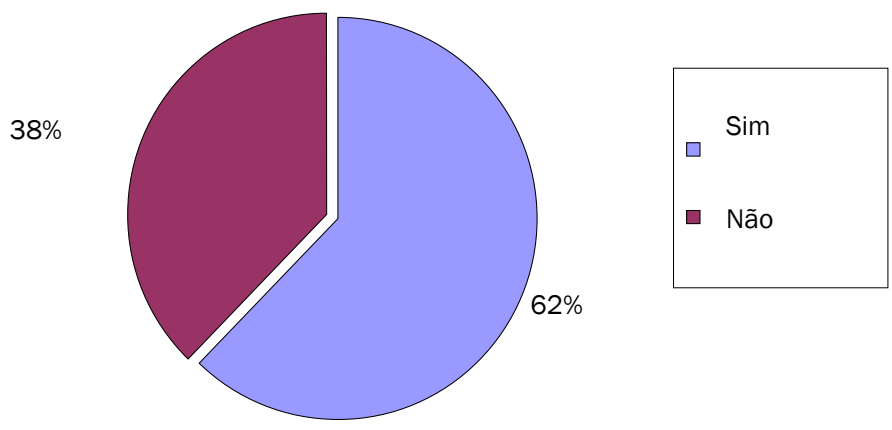

Figura 10: Percentual dos Pescadores que já Trabalharam com a Atividade Turística;
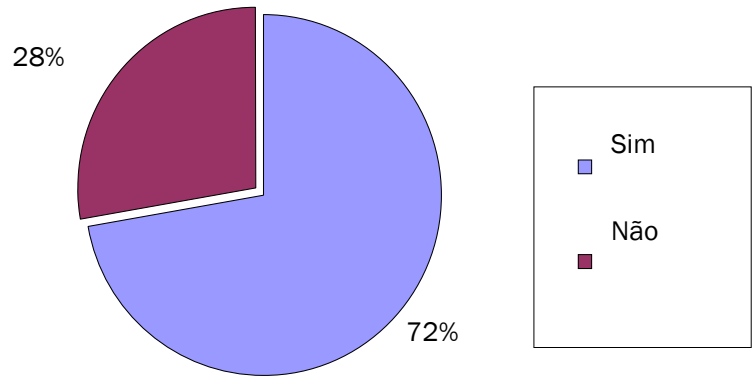

Figura 11: Atividades Desenvolvidas pelos Pescadores que Trabalharam com a Atividade Turística.

Em face desta configuração, um prospecto de diminuição da pesca amadora na região faz com que os pescadores profissionais prejudiquem seus meios de obtenção de renda, muitos não dispondo, notadamente, de meios que Ihes garantam ao menos sua subsidência.

Quanto aos pescadores profissionais que responderam que nunca trabalha- 
ram com atividade do turismo, que perfaz notadamente $38 \%$ dos pesquisados (Figura 10), muitos justificaram que foi por nunca terem tido oportunidade (19\%); outra importante parcela, neste mesmo ínterim, se divide entre os que disseram que o setor paga pouco (3\%), não conhecem as atividades do turismo (9\%) ou não tem interesse (6\%); o restante dos pesquisados que não trabalharam com a atividade do turismo (63\%) não alegaram motivos específicos para tanto (Figura 12).
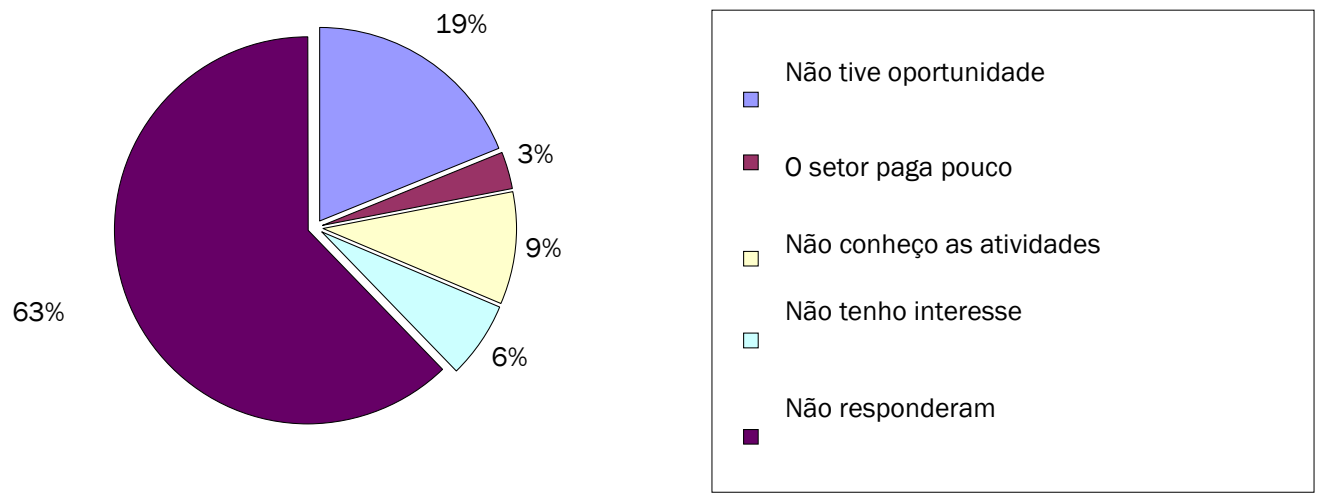

Figura 12: Percentual dos Motivos que Levaram os Pescadores Profissionais a não Trabalharem na Atividade do Turismo.

O que mais chama a atenção, nesse ínterim, é a questão da falta de oportunidades ser importante responsável por essa realidade, que vem opor-se ao que a própria pesquisa revelou, qual seja a constatação de que a grande maioria dos pescadores gostaria de participar das atividades do turismo.

Assim, no que tange ao interesse dos pescadores profissionais pesquisados em trabalhar com alguma atividade turística, $72 \%$ demonstraram que possuem tal interesse. Para estes, dentre as atividades que Ihes atraem estão: Piloteiro (46\%); Catador de Iscas (4\%); Guia de Pesca (13\%); Barco-Hotel (24\%); e Guia Turístico (13\%). O que torna a questão interessante é o fato de que, das atividades citadas, as três primeiras são estritamente atreladas ao turismo de pesca, o que revela a intensa relação que alguns pescadores nutrem com este segmento turístico em específico (Figura 13). 
Mariani, M. A. P.; Amarilio, F. L.; Arruda, D. O.
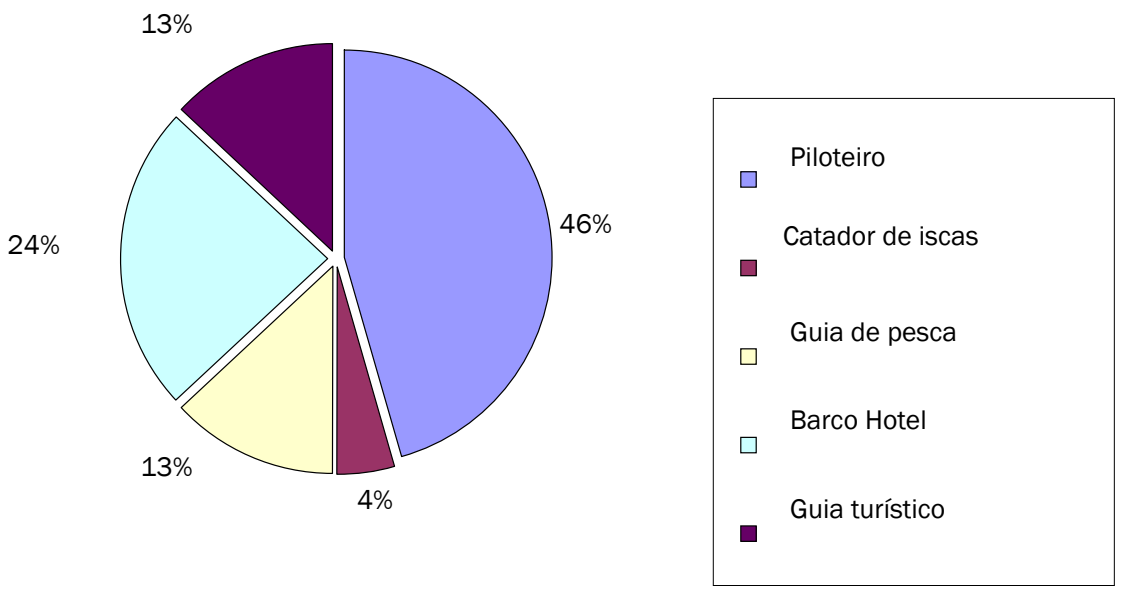

Figura 13: Percentual das Atividades que os Pescadores Profissionais Gostariam de Desenvolver, Atreladas ao Turismo.

Não obstante, as duas últimas atividades citadas (Barco-Hotel e Guia Turístico) podem ser utilizadas para o fomento do Ecoturismo, dado que a primeira destina-se a incorporar o pescador profissional no trato direto com o turista, ao passo que a última visa a utilizar o conhecimento popular dos pescadores na apresentação dos recursos turísticos da cidade, uma vez que estes indivíduos, por serem típicos da localidade, conhecem-na profundamente.

Conforme se revelou na apresentação do fragmentário teórico acerca do Ecoturismo, a explanação de manifestações culturais, bem como do conhecimento popular, podem constituir produtos turísticos de uma dada localidade, que atraem, pois, ecoturistas.

No que tange, pois, aos locais turísticos que os pescadores profissionais pesquisados conhecem, obteve-se a seguinte configuração: Hotéis-Fazendas (28\%); Serras (5\%); Estrada-Parque Pantanal (4\%); Área de Pesca (29\%); Rios, com exceção do Rio Paraguai, que margeia Corumbá (20\%); Pantanal (14\%) (Figura 14). Dos demais locais, alegaram conhecer: Portos (8\%); Fronteiras (2\%); Locais Urbanos (24\%) (porcentagem não representada graficamente). Ressalte-se que, nesta indagação do questionário, permitia-se ao pesquisado externar mais de uma resposta.

Desta feita, denota-se que são variados os locais turísticos conhecidos pelos pescadores profissionais, o que também corrobora a questão de que são profundos conhecedores da localidade em voga e estabelecem, assim, estreita relação com a mesma. Tal peculiaridade local é indelével atrativo de turistas praticantes do Ecoturismo. 

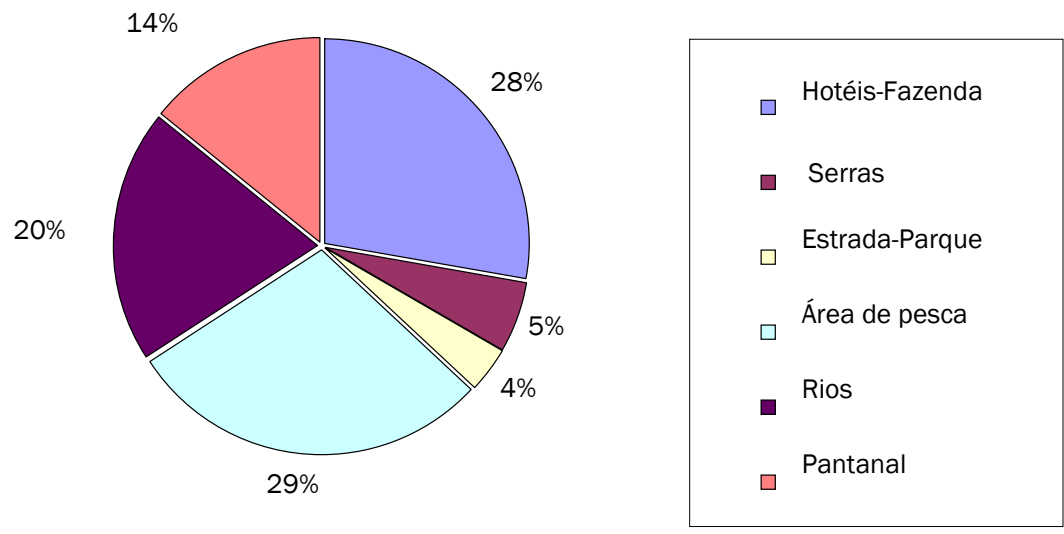

Figura 14: Locais Turísticos de Corumbá que os Pescadores Profissionais Conhecem.

Um aspecto intrigante reside no fato de que, a despeito da constatação de que muitos pescadores profissionais conhecem vários locais do município de Corumbá, falta-lhes ainda conhecer as atividades turísticas que podem ser desenvolvidas nesses espaços e como o seu conhecimento tradicional pode contribuir para o fomento da atividade do turismo e para a sua inserção na mesma.

Como prova de que falta conhecimento por parte do pescador acerca do que podem desenvolver está na indagação quanto às atividades, ligadas ao turismo, as quais gostariam de se integrar. Surgiram, notadamente, apenas cinco respostas (Piloteiro, Catador de Iscas, Guia de Pesca, Barco-Hotel e Guia Turístico), sendo que as três primeiras são estreitamente atreladas ao turismo de pesca.

Ressalte que o Ecoturismo, conforme já se debateu anteriormente, apresenta uma gama de atividades que podem ser desenvolvidas, utilizando, pois, as especificidades dos pescadores profissionais e ainda preservando os recursos naturais do Pantanal Sul-Mato-Grossense.

\section{Recursos que Atraem os Turistas}

Conhecer a percepção dos pescadores profissionais quanto às condições básicas da cidade de Corumbá que atraem o turista é relevante para que se tenha uma noção da intensidade que os mesmos podem integrar-se à atividade do turismo.

Assim, para 87\% dos pescadores profissionais pesquisados, Corumbá apresenta condições básicas suficientes para receber aporte cada vez mais crescente de turistas. Dentre os motivos que os levaram a tal constatação, 15\% alegaram ser 0 grande número de barcos-hotéis existentes na cidade; 35\% alegaram ser a infraestrutura, de um modo geral; ao passo que 38\% julgaram o próprio Pantanal a principal condição que a cidade oferece como chamariz de turistas (Figura 15). 
Desta feita, observa-se que, na opinião dos pescadores, os recursos naturais da localidade são o principal atrativo que ela apresenta. A conservação destes recursos, nesse viés, é indelével meio de garantia da manutenção da atividade turística em Corumbá.

Em contrapartida, para 13\% dos pescadores profissionais pesquisados, Corumbá não apresenta meios suficientes para atração de turistas. Dentre os motivos que os levaram a tal constatação, observa-se a falta de infra-estrutura básica e escassez de investimentos para 5\% e 8\%, respectivamente (Figura 15).
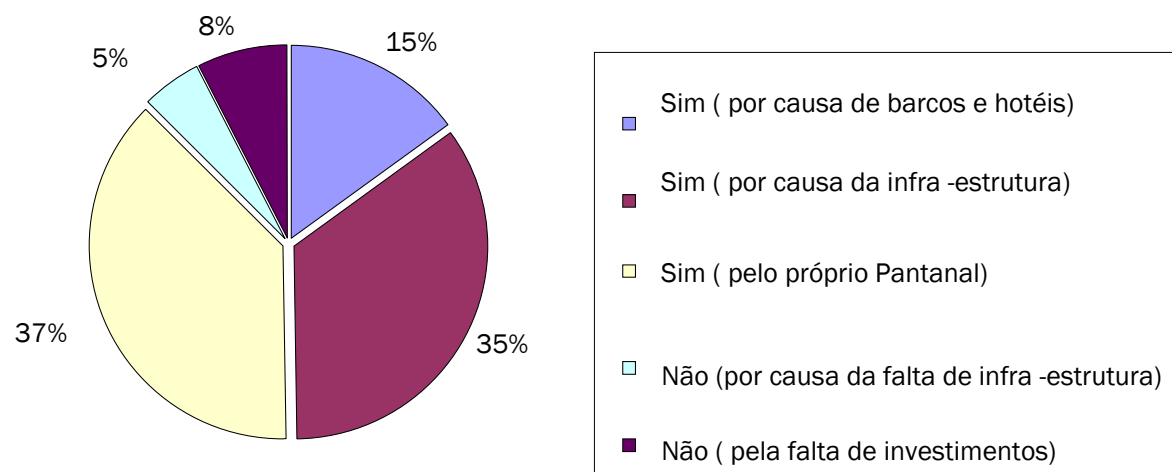

Figura 15: Percepção dos Pescadores Profissionais quanto às Condições de Corumbá de Receber Turistas.

Tratando aos quesitos de Corumbá que deveriam receber melhoras para atrair maior contingente de turistas, os pescadores profissionais pesquisados externaram o seguinte: melhorar o acesso à cidade (28\%); melhorar o nível dos restaurantes (6\%); melhorar a infra-estrutura (53\%); e melhorar o nível das hospedagens (13\%).

Então, pelo exposto, depreende-se notável preocupação dos pescadores no que se refere à infra-estrutura oferecida aos visitantes. Eles são conhecedores, pois, da nova configuração do turismo contemporâneo, que requer condições de infraestrutura cada vez mais sofisticas como meio de aração de turistas e de agregação de valor ao produto turístico oferecido.

\section{Benefícios para a Cidade de Corumbá, com o Fomento do Turismo}

Quanto aos principais benefícios decorrentes do fomento da atividade turística em Corumbá, $97 \%$ dos pescadores profissionais pesquisados revelaram que entre os mais notáveis estão: a geração de maior número de empregos (44\%); mais renda pa- 
ra a cidade, decorrente da arrecadação de mais impostos (35\%); além de progresso mais rápido, resultante da necessidade de maiores investimentos para atender aos turistas (19\%). Não obstante, 3\% dos pescadores responderam que o fomento da atividade do turismo não trará benefício algum para a cidade (Figura 16).

Esse resultado revela, notadamente, uma percepção e um conhecimento, mesmo que de forma empírica, por parte dos pescadores, no que se refere à movimentação econômica trazida pelo turismo.

Correlacionando esta constatação com a percepção que os pescadores profissionais têm da atividade turística, onde 55\% afirmaram concebê-la como fonte de renda, observa-se a necessidade destes indivíduos por melhores rendas e a convicção que eles têm na atividade turística como mecanismo de fomento de uma pujança econômica na cidade
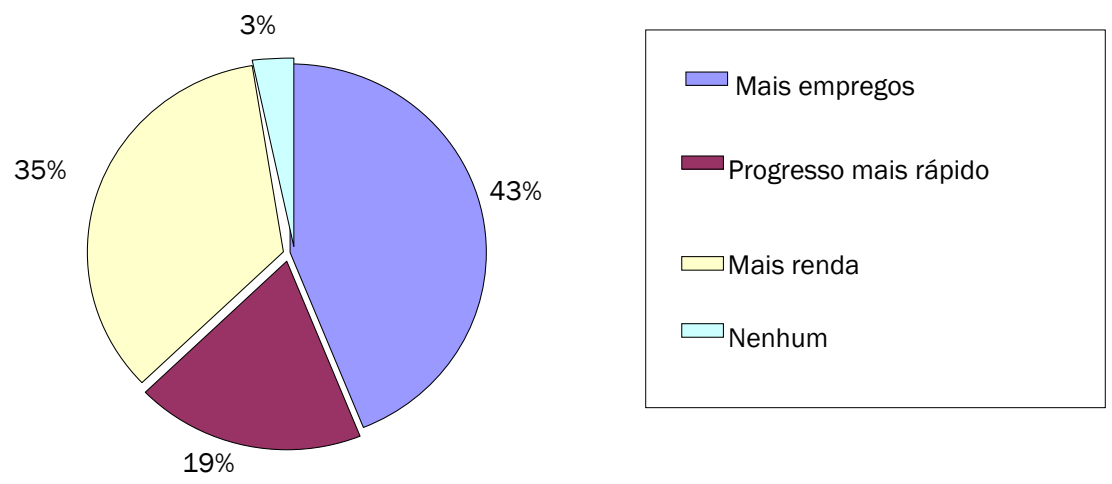

Figura 16: Benefícios que o Fomento do Turismo pode Trazes para a Cidade de Corumbá.

\section{Atuação do Poder Público quanto a Iniciativas de Promoção do Turismo}

Saber a percepção dos pescadores profissionais acerca dos incentivos do poder público para a promoção do turismo em Corumbá é interessante para se ter uma idéia da concepção, pelas comunidades, da atuação e importância das iniciativas públicas.

Para $62 \%$ dos pescadores profissionais pesquisados, a prefeitura de Corumbá tem incentivado a promoção e fomento da atividade turística (Figura 17). Dentre os motivos que os levaram a tal constatação está, como mais relevante, o oferecimento de boa infra-estrutura, por parte do governo, ao turista. Dentre tais recursos estão, notadamente, as centrais de atendimento ao turista, além dos festivais que são promovidos periodicamente como meio de divulgação das especificidades locais, como o Festival América do Sul. 


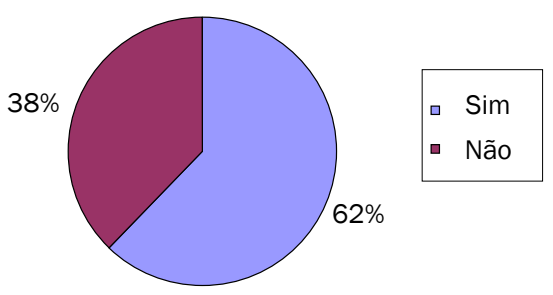

Figura 17: Percepção dos Pescadores Profissionais quanto a Atuação do Poder Público no Fomento ao Turismo.

À revelia deste fato, 38\% dos indivíduos pesquisados revelaram que são tímidas as atuações do poder público no que tange à promoção do turismo. Ademais, segundo eles, tem-se privilegiado sobremaneira o turismo de eventos, ao passo que outras modalidades de turismo, como o Ecoturismo, recebem parcos e escassos incentivos.

\section{Formas de Lazer da Cidade}

Nos momentos de lazer, quando não estão envolvidos com a pesca, os pescadores costumam assistir a TV $(24 \%)$ ir à igreja (6\%), tomar tereré, que é uma bebida típica da região (5\%) ou jogar futebol com os amigos (30\%) (Figura 18). Porém, o que merece destaque é que grande número de pescadores, mesmo em um momento de lazer, vai pescar, ou seja, a pesca, além de ser atividade econômica é atividade de lazer. Dos indivíduos pesquisados, $18 \%$ afirmaram ter tal costume. Assim os pescadores podem, portanto, deixar de ter a pesca como principal atividade econômica sem, no entanto, deixar de pescar, considerando-a uma atividade de lazer.
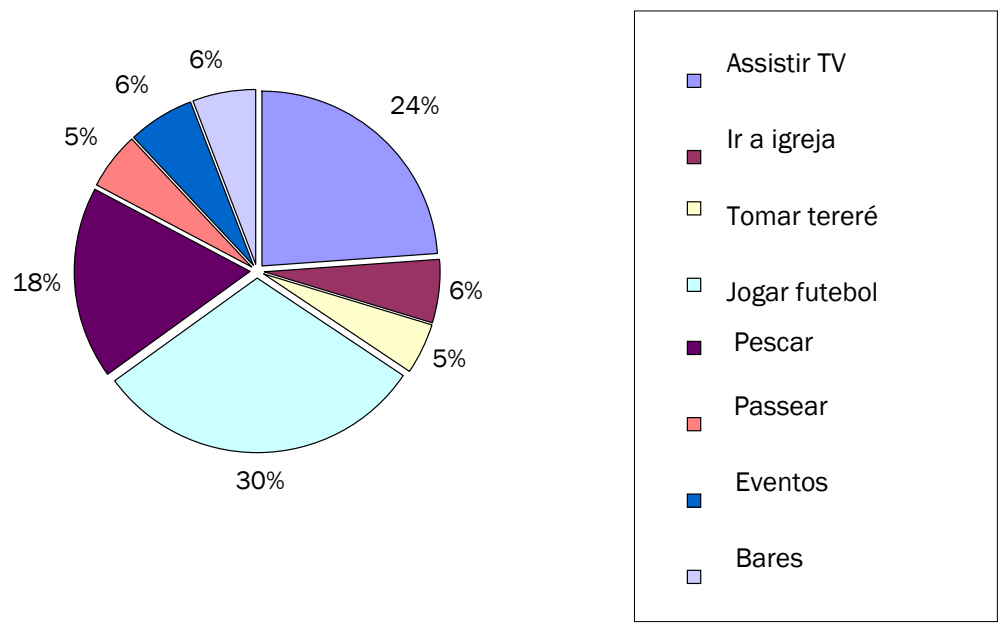

Figura 18: Atividades que os Pescadores Profissionais Desenvolvem nas Horas de Lazer. 


\section{CONSIDERAÇÕES FINAIS}

A implantação e fomento, de forma não planejada, da atividade turística, seja em qualquer uma de suas amplas dimensões, implicam na ocupação desordenada de espaços onde a população local sobrevivia, o que desencadeia impactos negativos na esfera biótica, física, social, econômica e cultural da região analisada.

A proposta para a implantação de uma política de turismo com base local tem um papel fundamental no desenvolvimento equilibrado da atividade turística, revertendo, na medida do possível, os impactos negativos (sejam eles de quaisquer ordens) causados pela instalação e desenvolvimento dessas atividades.

Para que isso aconteça de forma integrada com o planejamento pensado pelo poder público, é importante que essa política tenha alguns objetivos, quais sejam:

- $\quad$ O aumento da consciência da população no que se refere à qualidade do ambiente e à necessidade de sua conservação, considerando os impactos ambientais e sócio-econômicos das atividades do turismo na região, de modo a evitar ou reduzir tanto quanto possível os efeitos negativos e reforçar ao máximo os positivos;

- $\quad$ A promoção das culturas locais visando à criação de benefícios e oportunidades para as comunidades locais;

- $\quad$ A formação de bases de informações e disseminação do conhecimento nas localidades;

- $\quad$ A supervisão dos projetos de desenvolvimento do turismo existentes, em andamento e a serem implantados;

- $\quad$ A promoção da educação e informação adequadas aos profissionais do segmento do turismo.

O presente estudo correlaciona as questões supracitadas, as quais tencionam a promoção do turismo em sua forma sustentável, com os anseios e percepções de um grupo relevante da cidade de Corumbá, quais sejam: os pescadores profissionais urbanos.

No que tange à Corumbá, que compreende o locus de análise deste trabalho, ressalte-se que é uma cidade que apresenta vastos recursos naturais, uma vez que engloba boa parte do Complexo do Pantanal, ao passo que também possui indeléveis recursos sociais e culturais, dado que faz fronteira com dois países distintos (Paraguai e Bolívia), sendo aporte de pessoas de ambas as localidades, o que contribui para a efervescência cultural da área, além das manifestações típicas de grupos da região, como os pescadores profissionais.

Boa parte do crescimento e desenvolvimento de Corumbá esteve estreitamente atrelado ao fenômeno da pesca, seja em sua forma profissional ou amadora, a qual foi praticada em larga medida na região em virtude dos vastos rios piscosos que a mesma apresenta, como o Rio Paraguai. Tradicionalmente, a pesca era exerci- 
da pelos pescadores profissionais, que capturavam artesanalmente o pescado e o vendiam em sua forma in natura. Porém, com o desenvolvimento do turismo de pesca na região, houve severa diminuição da atividade pesqueira profissional.

Dentre os fatos que explicam esta queda pode-se citar a crescente diminuição dos estoques de pescado em virtude do crescimento vertiginoso da pesca amadora na região; além da migração de muitos pescadores profissionais para a atividade do turismo de pesca, dadas as demandas que este setor apresenta e o maior valor agregado que oferecem as suas atividades correlacionadas.

Desta feita, depreende-se, pois, que o turismo de pesca cresceu a passos largos em Corumbá de forma negligente e sem um devido planejamento prévio, dado que forçou muitos pescadores profissionais a abandonarem suas atividades típicas, além de exercer pressão sobre os recursos naturais, fato este corroborado pela diminuição das reservas de pescado dos rios.

Assim sendo, houve a necessidade da criação de mecanismos que objetivassem coibir a prática irresponsável do turismo de pesca na região. Então, sobretudo após boletins do sistema de controle da pesca do Mato Grosso do Sul realizados pela SCEPESCA/MS (1994, 1995, 1996, 1997, 1998 e 1999), acirrou-se a fiscalização acerca da prática da pesca amadora nos rios de Corumbá, o que contribui para a efetivação de um prospecto de constante declínio do turismo de pesca. Isso fez, notadamente, com que muitos pescadores profissionais se ressentissem, dado que alguns deles dependiam da pujança da pesca amadora como meio de garantir sua própria subsistência.

Um meio alternativo para solucionar tal problemática é, pois, a promoção do Ecoturismo, que apresenta possibilidades de se desenvolver em Corumbá, e procura aliar o protagonismo sócio-econômico da localidade à conservação dos recursos naturais da mesma.

Conhecer os anseios e relações que os pescadores profissionais estabelecem com a atividade turística sustentável é extremamente importante para iniciativas pontuais que visem ao atendimento dos anseios deste grupo, bem como à promoção do Ecoturismo, que é uma alternativa viável para o desenvolvimento sócio-econômico de Corumbá.

Assim, face ao perfil dos pescadores profissionais urbanos que se obteve com a efetivação da pesquisa de campo em alguns bairros de Corumbá, constatou-se que, no que tange ao quesito fonte de renda, boa parte dos pescadores profissionais pesquisados (64\%) não possui outros meios de geração de renda fora a pesca profissional. Dentre os fatos que explicam tal constatação está, sobretudo, a baixa capacitação que possuem, uma vez que apenas $25 \%$ do grupo pesquisado participou de algum curso de capacitação que Ihes propiciassem desenvolver alguma atividade mais específica.

Isso demonstra, notadamente, que a pesca profissional é exercida por indiví- 
duos que não possuem capacitação para o desenvolvimento de outras atividades. Não obstante, quando indagados se gostariam de participar de cursos de capacitação, 72\% demonstraram notável receptividade, sobretudo para cursos ligados à atividade turística.

Nesse ínterim, quando questionados acerca de como concebem a atividade turística praticada na região, expressivo contingente de pescadores profissionais (55\% dos pesquisados) afirmou ser fonte de renda, do que denota-se que uma das principais demandas destes indivíduos é, justamente, a percepção de melhores rendas, uma vez que expressivo contingente deles gostaria de se integrar a atividade turística.

Uma especificidade deste grupo é, pois, o exacerbado conhecimento que têm das especificidades da região e dos potenciais recursos turísticos que ela apresenta. Isso expressa a verdadeira simbiose que os pescadores profissionais têm com o local, uma vez que muitos nasceram e viveram na cidade, conhecendo os seus estágios de desenvolvimento, dado que a pesca é praticada, sobretudo, por indivíduos de meiaidade.

Não obstante, à revelia deste profundo conhecimento da região, falta aos pescadores conhecimento acerca das atividades turísticas que podem ser praticadas na localidade, uma vez que, quando indagados acerca das atividades ligadas ao turismo que gostariam de desenvolver, boa parte das respostas obtidas são, direta ou indiretamente, ligadas a pesca.

É notória também a percepção dos pescadores no que tange aos benefícios oriundos do fomento à atividade turística para a cidade de Corumbá. Dos pesquisados, 97\% afirmaram que o turismo traz vantagens expressivas para o município, dentre as quais: maior número de empregos; progresso; e renda.

Assim, face às especificidades apresentadas acerca das percepções dos pescadores profissionais, entende-se que uma possibilidade para o fomento do Ecoturismo é a promoção, sobretudo pelo poder público, de cursos de capacitação que visem a destinar os pescadores a atividades onde o seu saber possa ser intensamente aproveitado como produto turístico da região. Dentre tais atividades estão, sobretudo, as de guias turísticos, onde há a explanação das culturas locais para os turistas e há a tomada de consciência acerca da necessidade de preservá-las.

Ressalte-se que não se pretende, com a proposição dessas iniciativas e com o esquadrinhamento da possibilidade de inserção dos pescadores na atividade turística, desviá-los da pesca profissional. Muito pelo contrário. A pesca constitui para seus praticamente típicos uma manifestação cultural, que deve ser resguardada e mantida.

Prova fidedigna disto é o fato de que, na aplicação dos questionários, uma vez indagados acerca das atividades que desenvolviam em suas horas de lazer, 18\% dos pescadores profissionais pesquisados relataram que pescam em suas horas de folga. Assim, além da pesca constituir a principal fonte de renda desses indivíduos, ainda representa uma atividade de lazer, corroborando a questão cultural externada pela pesca. 
Por fim, faz-se imprescindível citar que tais medidas não são meios comprovadamente eficazes de fomento do turismo sustentável na cidade de Corumbá. Elas são fruto dos questionários aplicados e das reflexões feitas na pesquisa em voga, e constituem, pois, mera gota de conhecimento sobre um oceano de possibilidades para o desenvolvimento da região em questão.

\section{REFERÊNCIAS BIBLIOGRÁFICAS}

BENI, M.C. Análise estrutural do turismo. São Paulo: SENAC, 1998.

BRASIL. MICT/MMA. Grupo de Trabalho Interministerial. Diretrizes para uma política nacional de Ecoturismo. Brasília: EMBRATUR/IBAMA, 1994a.

BRASIL. Ministério do Turismo. Manual de Ecoturismo. Brasília:EMBRATUR, 1994b.

CATELLA, A. C. A Pesca no Pantanal de Mato Grosso do Sul, Brasil: Descrição, Nível de Exploração e Manejo (1994 - 1999). 2001. 351p. Tese (Doutorado em Ciências Biológicas), Instituto nacional de Pesquisas da Amazônia - INPA / Universidade do Amazonas - UA, Manaus. 2001.

CATELLA, A. C. A pesca no Pantanal Sul: situação atual e perspectivas. Corumbá: Embrapa Pantanal, 2003, 43p.

CMMAD - COMISSÃO MUNDIAL SOBRE AMBIENTE E DESENVOLVIMENTO. Nosso futuro comum. Rio de Janeiro: FGV, 1988.

ITO, C. A. Corumbá: o espaço da cidade através do tempo. Campo Grande: UFMS, 2000.

LAGE, B.H.G.; MILONE, P.C.(orgs). Turismo: teoria e prática. São Paulo: Atlas, 2000.

LINDBERG, K.; HAWKINS, D.E. Ecoturismo: um guia para planejamento e gestão. São Paulo: SENAC, 1995.

OLIVEIRA, L. D.; PINHEIRO, L. E. L.; MICHELS, I. L.; BRUM, E. A organização da atividade turística em Corumbá, sob o enfoque dos conceitos de cadeia produtiva e arranjo produtivo local. Revista Pasos, v. 6, nº 3, 2008, pp. 511-522.

PANOSSO-NETTO, A. Filosofia do turismo: teoria e epistemologia. São Paulo: Aleph, 2005.

PIRES, P.S. A dimensão conceitual do Ecoturismo. Turismo visão e ação, v.1, $\mathrm{n}^{\circ} 1$, 1998, pp. 75-91.

RUSCHMANN, D. V. M. Turismo e planejamento sustentável: a proteção do meio ambiente. Campinas: Papirus, 1997.

RUSCHMANN, D.V.M. A experiência do turismo ecológico no Brasil: um novo nicho de mercado ou um esforço para atingir a sustentabilidade. Turismo visão e ação, v.2, n० 5, 2000, pp. 81-90. 
SCPESCA/MS, Boletim do sistema de controle da pesca do Mato Grosso do Sul, n. 1, 1994.

SCPESCA/MS, Boletim do sistema de controle da pesca do Mato Grosso do Sul, n. 2, 1995.

SCPESCA/MS, Boletim do sistema de controle da pesca do Mato Grosso do Sul, n. 3, 1996.

SCPESCA/MS, Boletim do sistema de controle da pesca do Mato Grosso do Sul, n. 4, 1997.

SCPESCA/MS, Boletim do sistema de controle da pesca do Mato Grosso do Sul, n. 5, 1998.

SCPESCA/MS, Boletim do sistema de controle da pesca do Mato Grosso do Sul, n. 6, 1999.

SMTUR (SECRETARIA MUNICIPAL DE TURISMO DE CORUMBÁ). Trade Turístico. Corumbá: SMTUR, 2003.

SOUZA, R. S.; JUNIOR, N. A.; ÁVILA, V. F.; MARTINS, S. R. O. Comunidade e desenvolvimento local: os pescadores profissionais de Corumbá. Anais do IV SIMPAN/ MS: Corumbá, 2004.

Milton Augusto Pasquotto Mariani: Universidade Federal do Mato Grosso do Sul (UFMS) - Departamento de Economia e Administração (DEA)

Email: miltmari@terra.com.br

Link para o currículo Lattes: http://lattes.cnpq.br/0935409945176042

Francisco Leonor de Amarilio: Universidade Federal do Mato Grosso do Sul (UFMS)

Link para o currículo Lattes: http://lattes.cnpq.br/6604874374411111

Dyego de Oliveira Arruda: Universidade Federal do Mato Grosso do Sul (UFMS) Departamento de Economia e Administração (DEA)

Email: dyego.arruda@gmail.com

Link para o currículo Lattes: http://lattes.cnpq.br/5222976964204691

Data de submissão: 07 de novembro 2008

Data do aceite: 08 de julho de 2009 